\title{
Method for Determining the Optimum Insulation Thickness of the Plaster Tow Material: Influence of the Heat Exchange Coefficient in Transient Regime
}

\author{
\# corresponding author \\ Type of Work: Peer Reviewed. \\ DOI: 10.21013/jas.v16.n3.p2 \\ DOI URL: https://dx.doi.org/10.21013/jas.v16.n3.p2
}

Papa Touty TRAORE ${ }^{1}$, Fatimata BA ${ }^{1}$, Babou DIONE ${ }^{1 \#}$ (D), and Moussa DIENG ${ }^{1}$

${ }^{1}$ Physical Department, University Cheikh Anta Diop of Dakar, 5005 Dakar, Senegal.

\section{How to cite this paper:}

TRAORE, P.T. et al. (2021). Method for Determining the Optimum Insulation Thickness of the Plaster Tow Material: Influence of the Heat Exchange Coefficient in Transient Regime. IRAInternational Journal of Applied Sciences (ISSN 2455-4499), 16(3), 53-58.

DOI: https://dx.doi.org/10.21013/jas.v16.n3.p2

(C) IRA Academico Research.

(cc) BY-NC

This work is licensed under a Creative Commons Attribution-NonCommercial 4.0 International License subject to a proper citation to the publication source of the work.

Disclaimer: The scholarly papers as reviewed and published by IRA Academico Research are the views and opinions of their respective authors and are not the views or opinions of IRA Academico Research. IRA Academico Research disclaims any harm or loss caused due to the published content to any party.

IRA Academico Research is an institutional publisher member of Publishers International Linking Association Inc. (PILA-CrossRef), USA. IRA Academico Research is an institutional signatory to the Budapest Open Access Initiative. Hungary advocating the open access of scientific and scholarly knowledge. IRA Academico Research is a registered content provider under Open Access Initiative Protocol for Metadata Harvesting (OAI-PMH).

The journal is indexed \& included in WorldCat Discovery Service (USA), CrossRef Metadata Search (USA), WorldCat (USA), OCLC (USA), Open J-Gate (India), EZB (Germany) Scilit (Switzerland), Airiti (China), Bielefeld Academic Search Engine (BASE) of Bielefeld University, Germany, PKP Index of Simon Fraser University, Canada. 


\section{ABSTRACT}

In this paper, we have applied a numerical method to determine the optimum insulation thickness of the tow plaster plane material. The influence of the exchange coefficients at the level of the two faces of the material has been highlighted. The optimum insulation thickness of the material is at the area where the thermal resistance value of the material is the maximum. We added the relative thermal resistance to show how the optimum insulation thickness changes when the exchange coefficients change values.

Keywords: Optimal thickness, Insulation, Heat exchange coefficient, Thermal resistance

\section{Introduction}

The high energy consumption [1] was caused by air conditioning in buildings and prompted researchers to focus on the characterization of high performance local insulating materials to improve thermal comfort [2] of buildings and save energy and money it is important to use local materials that are available and easy to use, hence the interest of insulating the hearths with an insulating material [3] with a small thickness to amortize the cost of investment. In this work, we determined the optimum insulation thickness [4] of the plaster tow material. The proposed method is based on the determination of the thermal resistance in the depth of the material for a different value of heat exchange coefficient. We also used the relative thermal resistance that shows how the optimum insulation thickness of the material changes when the heat exchange coefficients change values [5].

\section{Material and Method}

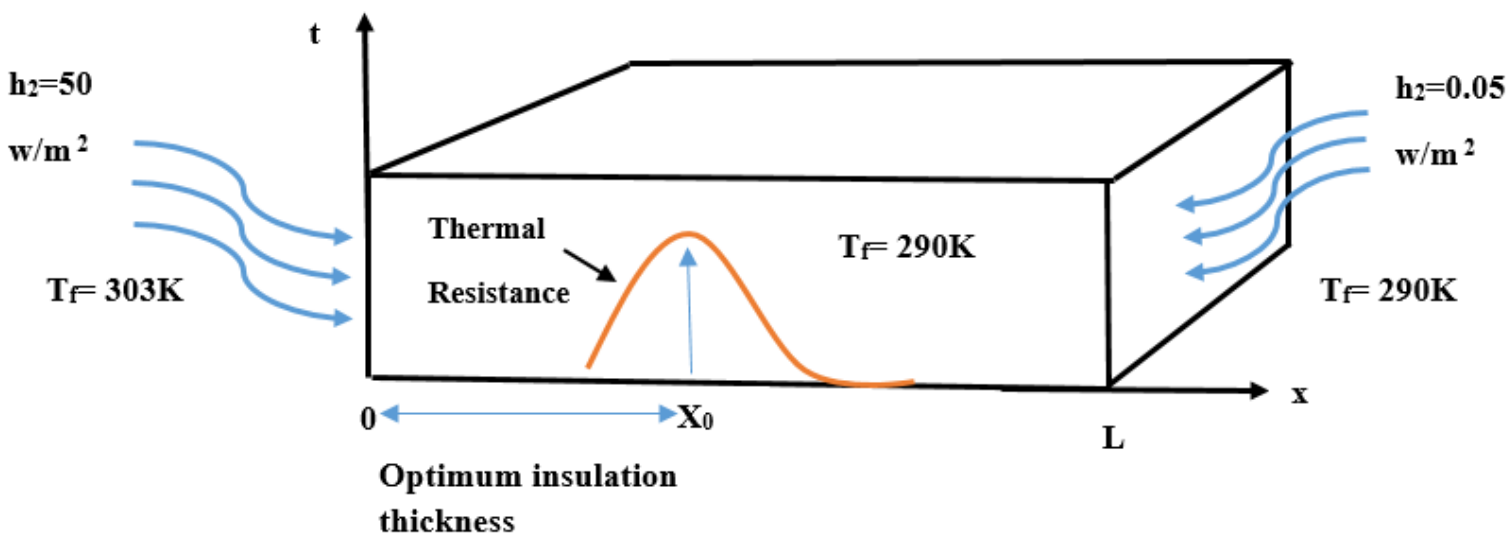

Fig. 1: Tow plaster plane material

The equation for heat without a heat sink is given by the following expression

$$
\frac{\partial^{2} T(x, t)}{\partial^{2} x}-\frac{1}{\alpha} \frac{\partial T(x, t)}{\partial x}
$$

Where $\alpha=\frac{\lambda}{\rho c}$

$\boldsymbol{\alpha}$ is the thermal diffusivity of the material assumed to be uniform.

$\lambda$ is the thermal conductivity of the material

c the specific heat

Equations (2) and (3) reflect the conservation of heat flux at the surface of the material and equation (4) represents the initial condition.

$$
\left\{\begin{array}{l}
h_{1}\left(T(0, t)-T_{f 1}\right)=\lambda \frac{\partial T(x, t)}{\partial t} \mid x=0 \\
h_{1}\left(T(L, t)-T_{f 2}\right)=\lambda \frac{\partial T(x, t)}{\partial t} \mid x=L \\
T(x, 0)=T^{0}
\end{array}\right.
$$


The finite-difference discretization method applied to the equations allows us to obtain; the temperatures expressions on the two faces

Where,

$$
\left\{\begin{array}{l}
T_{i}^{j+1}=A T_{i}^{j}+2 P T_{2}^{j}+C T_{f 1} \\
T_{i}^{j+1}=B T_{i}^{j}+2 P T_{M-1}^{j}+D T_{f 2} \\
T_{i}^{1}=T^{0}
\end{array}\right.
$$

i locate the variable space

$\mathbf{j}$ is the locates the variable temp

$\boldsymbol{T}_{\boldsymbol{i}}^{\boldsymbol{j}}$ is the temperature at node $\mathrm{i}$ at date $\mathrm{j}$

M represents the number of nodes along the space $\mathrm{x}$

$\mathbf{N}$ the number of nodes along time $t$

The expression of the flux density

$$
\phi_{j}^{i}=-\lambda \frac{\left[T_{i+1}^{j}\left(h_{1}, h_{2}, \alpha\right)-T_{i}^{j}\left(h_{1}, h_{2}, \alpha\right)\right]}{\Delta x}
$$

The expression of the resistance in the discrete form:

Where $1 \leq i \leq M-1$ et $1 \leq j \leq N$

$$
R_{i}^{i}\left(\alpha, h_{1}, h_{2}\right)=\frac{T_{1}^{j}\left(\alpha, h_{1}, h_{2}\right)-T_{M}^{j}\left(\alpha, h_{1}, h_{2}\right)}{\phi_{i}^{j}\left(\alpha, h_{1}, h_{2}\right)}
$$

The relative constant of thermal resistance is defined by the following expression:

\section{Results and Discussion}

$$
R_{r}=\frac{R_{t h}}{R_{\max }}
$$

We have studied the influence of the heat exchange coefficient of the front face $\mathrm{h} 1$ on the evolution of the thermal resistance of the material at depth.

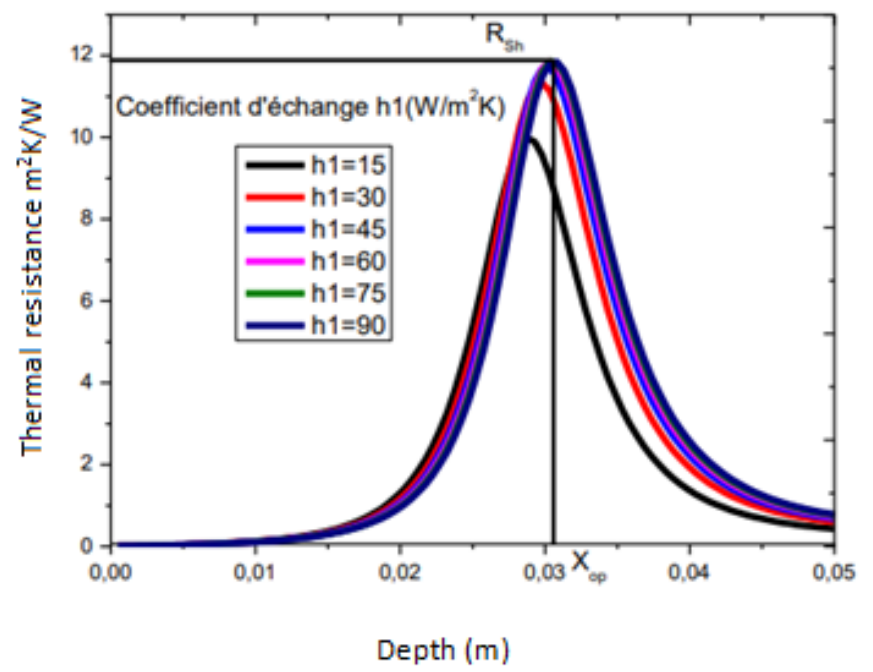

Fig 2: Evolution of thermal resistance as a function of depth - influences of heat exchange coefficient $\mathrm{h} 1 \mathrm{~W} / \mathrm{m}^{2} \mathrm{~K}$; $\mathrm{h} 2=5 \mathrm{~W} / \mathrm{m}^{2} \mathrm{~K} ; \mathrm{N}=100,000 ; \mathrm{M}=100 ; \mathrm{x}=5 \mathrm{~cm}$

The figure shows the evolution of the thermal resistance in the depth of the material. The resistive behaviour [6] of the material depends on the thickness of the material. For thicknesses between 0 and $1.5 \mathrm{~cm}$, the resistance of the 
material is very low therefore the heat passes through these thicknesses due to the proximity to the external environment. These characterize the area sensitive to stress outdoor climate; for thicknesses between 1.5 and $\mathrm{X}_{\mathrm{op}}$ the strength of the material increased and reached a maximum. This phenomenon reflects the retention heat. This shows the good thermal inertia of the material. The maximum attain by the resistance exhibits the thermal shunt effect (resistance to heat leakage) this takes place at optimum insulation thickness level; for thicknesses between $\mathrm{X}_{\mathrm{op}}$ and $5 \mathrm{~cm}$ thermal resistance slowly decreases from the optimum insulation thickness on the backside thickness; this diminutive translates the heat leak to the interior environment due to the effect of heat transfer coefficient of the rear face $h 2$.

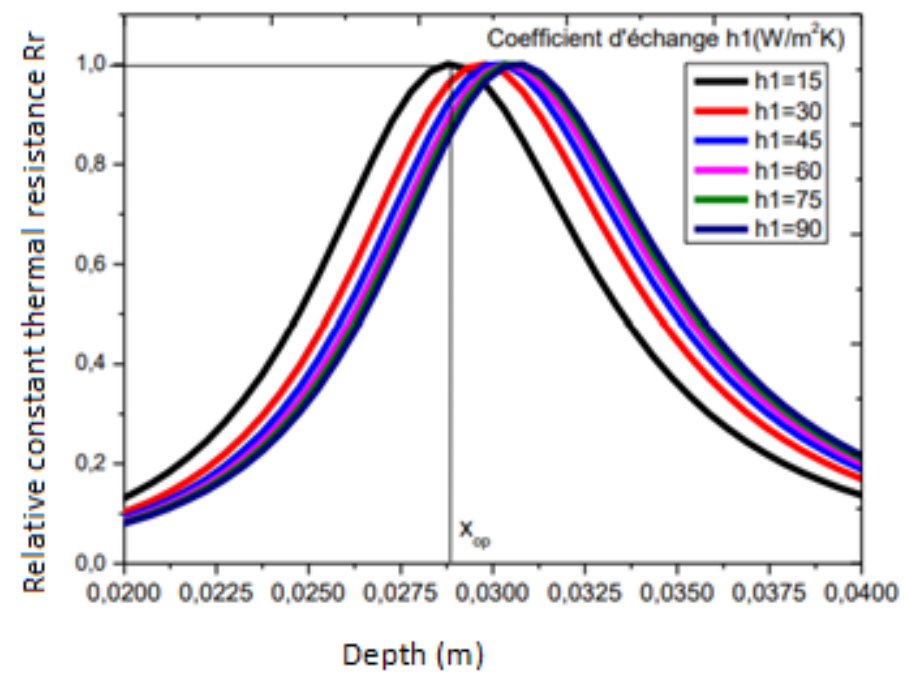

Fig 3: Evolution of the relative constant of resistance as a function of depth -influences of heat exchange coefficient h1 = 50 W/ m2K; h2 = 5 W/ m2K; $N=100,000 ; M=100$

The figure shows the evolution of the relative thermal resistance [7] in the depth of the material under the influence of the heat exchange coefficient at the front face h1. The interest of this figure is to see the displacement of the optimum insulation thickness as a function of the front face exchange coefficient $h_{1}$. We observe an increase in the latter when the exchange coefficient $h_{1}$ increases. In fact, the heat flow transmitted to the material increased with the exchange coefficient $h_{1}$ therefore there will be rapid diffusion of the thermal wave. So the attenuation of the thermal wave can only be done in-depth of the material, hence the optimal displacement of thermal insulation. However, the optimum thickness shifts very little which show the material is a good thermal insulator. The following table shows the optimum insulation thickness and the corresponding thermal shunt resistance

Table 1 influence of the heat exchange coefficient $h_{1}$ on the thermal shunt resistance and insulation thickness

\begin{tabular}{|l|l|l|l|l|l|l|}
\hline Heat exchange coefficient $\mathrm{h}_{1}(\mathrm{~W} / \mathrm{m} 2 \mathrm{~K})$ & 15 & 30 & 45 & 60 & 75 & 90 \\
\hline $\begin{array}{l}\text { Maximum resistance } \\
R_{\max }\left(\mathrm{m}^{2} \mathrm{~K} / \mathrm{W}\right)\end{array}$ & 11.32 & 12.40 & 12.64 & 12.75 & 12.71 & 12.63 \\
\hline Optimal insulation thickness Xop (m) & 0.028 & 0.029 & 0.029 & 0.029 & 0.030 & 0.030 \\
\hline
\end{tabular}

In this table, we observe an increase in maximum resistance for coefficient front face exchange includes between 15 $\mathrm{W} / \mathrm{m}^{2} \mathrm{~K}$ and $60 \mathrm{~W} / \mathrm{m}^{2} \mathrm{~K}$. For these value ranges of the heat exchange coefficient $\mathrm{h}_{1}$, the material as opposed to the diffusion of heat which translates increasing thermal maximum resistance. The optimum insulation thickness [8] is included between $2.8 \mathrm{~cm}$ and $3.03 \mathrm{~cm}$; which shows the good thermal inertia of the material. However, for exchange coefficients $\mathrm{h}_{1}$ greater than $75 \mathrm{~W} / \mathrm{m}^{2} \mathrm{~K}$ the maximum resistance decreases and the thickness optimum insulation remains constant and equal to $0.0303 \mathrm{~cm}$. With this small value of the thickness of the tow material, one can make good thermal insulation. 


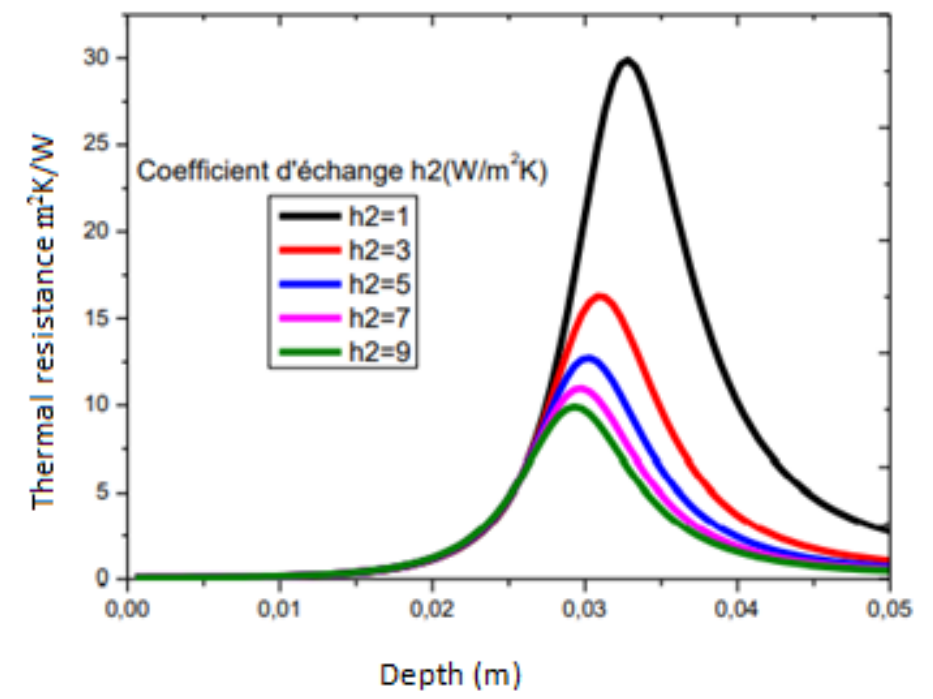

Fig 4: Evolution of thermal resistance as a function of depth - influence of heat exchange coefficient h1 W/m $\mathbf{h}^{2}$; h2 $=5 \mathrm{~W} / \mathrm{m}^{2} \mathrm{~K} ; \mathrm{N}=100,000 ; \mathrm{M}=100 ; \mathrm{x}=5 \mathrm{~cm}$.

The figure shows the resistive behaviour of the plaster tow material in depth. The resistance of the material is practically zero for thicknesses very close to the external environment; this is the area sensitive to climatic stress [8] from the external environment, the rear face exchange coefficients have no effect on the thermal resistance in the area. On the other hand, for thicknesses greater than $2 \mathrm{~cm}$, the resistance of the material increases in depth and reaches the maximum. This maximum reflects the phenomenon of heat retention and heat blocking. The decrease in thermal resistance in the vicinity of the rear face results in heat leaks to the interior environment. The increase in exchanges at the rear face between a decrease in the maximum resistance see table 2.

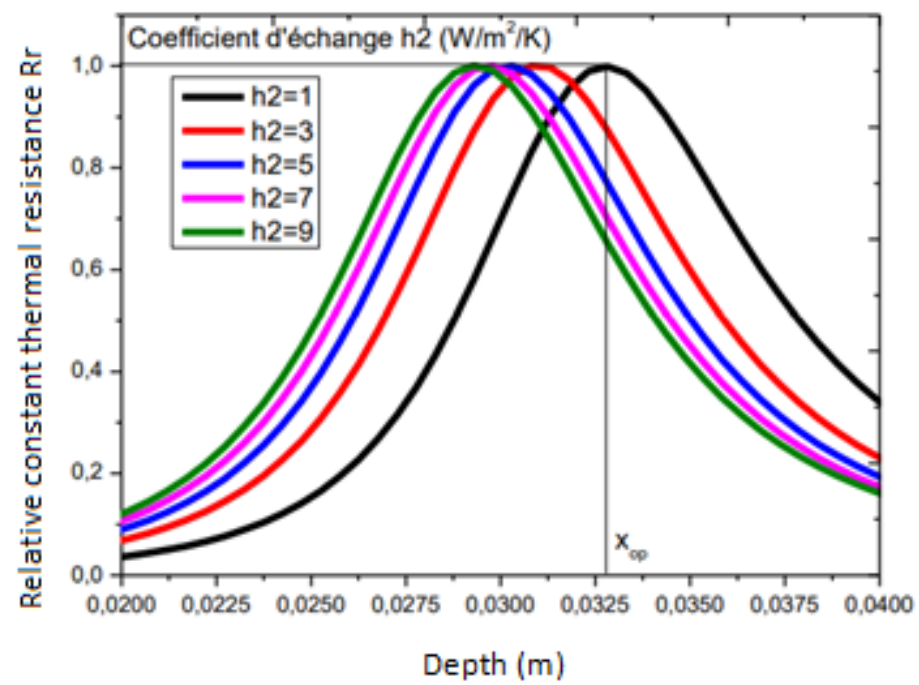

This figure shows the relative thermal resistance in the depth of the material under the influence of the convective exchange coefficient at the rear face. The study of the relative thermal resistance in-depth, allows us to see the displacement of the optimal thickness when we vary the heat exchange coefficient $h_{2}$. We observe a decrease in the optimal insulation thickness of the material when the coefficient $\mathrm{d} \mathrm{h} 2$ exchange increased. The increase in convective phenomena at the rear face (increase in the exchange coefficient $h_{2}$ ) causes heat leaks to the interior environment, hence this reduction. The values for shunt resistance and optimum insulation thickness $[9,10]$ are in Table 2. 
IRA-International Journal of Applied Sciences

Table 2: influence of the heat exchange coefficient $h_{2}$ on the thermal shunt resistance and insulation thickness

\begin{tabular}{|l|l|l|l|l|l|}
\hline Heat exchange coefficient $\mathrm{h}_{2}\left(\mathrm{~W} / \mathrm{m}^{2} \mathrm{~K}\right)$ & 1 & 3 & 5 & 7 & 9 \\
\hline $\begin{array}{l}\text { Maximum resistance } \\
R_{\max }\left(\mathrm{m}^{2} \mathrm{~K} / \mathrm{W}\right)\end{array}$ & 29.85 & 16.25 & 12.65 & 10.94 & 9.92 \\
\hline Optimal insulation thickness Xop (m) & 0.032 & 0.031 & 0.030 & 0.029 & 0.029 \\
\hline
\end{tabular}

\section{Conclusion}

In this work, we determined the optimum thermal insulation thickness of the tow material. The influence of heat exchange coefficients on the front and rear sides of the material to be put. The latter has little influence on the variation of the optimum insulation thickness. And the value of maximum optimum insulation thickness is approximately $3 \mathrm{~cm}$. With $3 \mathrm{~cm}$ of plaster tow material, we can make good thermal insulation.

\section{References}

[1]. Kon, Okan. (2017). Determination of optimum insulation thicknesses using economical analyse for exterior walls of buildings with different masses. An International Journal of Optimization and Control: Theories \& Applications (IJOCTA) 7, no. 2, 149-157

[2]. Y. Traore, E.B. Diaw, I. Diagne, M.B. Ndiaye, S. Tamba, B. Fleur, M. Dieng, A.K. Diallo And G. Sissoko (2016). Characterization Phenomena of Thermal Transfer through an Insulating Material Kapok Plaster Starting from Dynamic Impedance Method -Research Journal of Applied Sciences, Engineering and Technology. Maxwell Scientifique Publication Corp 12, $\mathrm{n}^{\circ}$ 7, 712-715.

[3]. H. L. Diallo, B. Dieng, I. Ly, M. M. Dione, M. Ndiaye O. H. Lemrabott, Z. N. Bako, A. Wereme and G. Sissoko (2012). Determination of the recombination and electrical parameters of a vertical multijunction silicon solar cell. Research Journal of Applied Sciences, Engineering and Technology 6, 1-6

[4]. I. K. Toure, M. S. O. Brahim, A. Diouf, M. Dieng, A. k. Diallo, B. Fleur, Y. Traore, I. Diagne, M. Wade, G. Sissoko (2016). 'Spectroscopic Analysis of Thermal Behaviour of Kapok-Plaster Material in Dynamic Frequency Regime Established-International Journal of Mechanical Engineering - ISSN 2321- 6441, Volume 4, Issue 7.

[5]. M. Dieng, I. Diagne, B. Fleur, A. Kane, M.L. Sow, F. Niang and G. Sissoko (2012). Study of heat transfer in a kapok material from the convective heat transfer coefficient and the excitation pulse of solicitations external climatic- Research Journal of Applied Sciences, Engineering and Technology-Maxwell Scientific Organization. ISSN: 2040-7459; e-ISSN: 2040-7467.pp, 1960- 1962.

[6]. A. K. Diallo, M. Boukar, M. B. Ndiaye, A. Diene, P. Demba, I. Diagne, M. S. O. Brahim and G. Sissoko (2014); Study of the equivalent electrical capacity of a thermal insulating kapok-plaster material in frequency dynamic regime established-Research Journal of Applied Sciences, Engineering and Technology-Maxwell Scientific Organization, ISSN: 2040-7459; e-ISSN: 2040-7467.pp,2141- 2145.

[7]. A. Diouf, I. Diagne, M.S. OulBrahim, M.L. Sow, F. Niang and G. Sissoko (2012). Study in Cylindrical Coordinates of the Heat Transfer Through a Tow Material-Thermal Impedance Research Journal of Applied Sciences, Engineering and Technology-Maxwell Scientific Organization. ISSN: 2040-7459; e-ISSN: 20407467.pp, 159-5163.

[8]. J.C. Batsale, A. Degiovanni, (1994). Mesure de résistance thermique de plaque mincesà l'aide d'une min-plaque chaude, Rev. Gen. Therm. 390-39.

[9]. E. K. M. Abdelgadir, A.M. H. Adam, O.Younis, A. K. Hussein (2019). Optimum Thermal Insulation Thickness for Building Under Different Climate Regions -A Review Journal of Advanced Research in Fluid Mechanics and Thermal Sciences 59, Issue 2254-268

[10]. D., Naouel. (2011). A study on optimum insulation thickness in walls and energy savings in Tunisian buildings based on analytical calculation of cooling and heating transmission loads. Applied Energy 88, no. 1 156-164. 